\title{
Eubacterium saphenus sp. nov., Isolated from Human Periodontal Pockets
}

\author{
HIROYUKI UEMATSU, FUTOSHI NAKAZAWA, TETSURO IKEDA, AND ETSURO HOSHINO* \\ Department of Oral Microbiology, Niigata University School of Dentistry, \\ Gakkocho-dori 2, Niigata 951, Japan
}

\begin{abstract}
A new species, Eubacterium saphenus sp. nov., established on the basis of the results of DNA-DNA hybridization, was proposed for strains isolated from human periodontal pockets. Differential characteristics are given.
\end{abstract}

Asaccharolytic strains of Eubacterium, which were obligately anaerobic, non-spore-forming, nonmotile, gram-positive short rods and produced moderate amounts of acetate and butyrate as end products, were isolated from human periodontal pockets and comprised $14 \%$ of a total of 422 isolates from patients with advanced periodontitis (10). According to criteria described in the Virginia Polytechnic Institute manual (2) and Bergey's manual (9), they most resembled $E$. nodatum of the established species of Eubacterium (9) but did not hydrolyze arginine (10), unlike $E$. nodatum. They also resembled Eubacterium strain D-6 (1) but did not produce phenylacetate as one of the end products (10), unlike Eubacterium strain D-6 (1). Thus, the isolates were tentatively classified as Eubacterium $\mathrm{U}$ group strains (10).

A DNA-DNA hybridization technique was adopted to evaluate the genetic relationship of the $U$ group strains to $E$. nodatum, Eubacterium strain D-6, and some other asaccharolytic Eubacterium species.

\section{MATERIALS AND METHODS}

Bacterial strains. E. saphenus U 133-14, U 146-24, U $164-47^{\mathrm{T}}$ ( $\mathrm{T}=$ type strain), $\mathrm{U} 175-34$, and $\mathrm{U}$ 183-27 were isolated from periodontal pockets of different patients. The isolation procedure used has been described in detail previously (10). E. nodatum ATCC $33099^{\mathrm{T}}$, E. brachy ATCC $33089^{\mathrm{T}}$, E. lentum ATCC $25559^{\mathrm{T}}, E$. timidum ATCC $33093^{\mathrm{T}}$, and E. limosum (type species) ATCC $8486^{\mathrm{T}}$ were obtained from the American Type Culture Collection. Eubacterium strain D-6 (D136M-28) was obtained from L. V. H. Moore. The bacterial cells were maintained on brain heart infusion (BHI)-blood agar plates (2) under strictly anaerobic conditions in an anaerobic glove box (model AZ-Hard; Hirasawa, Tokyo, Japan) containing $80 \% \mathrm{~N}_{2}, 10 \% \mathrm{H}_{2}$, and $10 \% \mathrm{CO}_{2}$ and stocked in a refrigerator at $4^{\circ} \mathrm{C}$ in the anaerobic glove box or in a freezer at $-80^{\circ} \mathrm{C}$. The plates, media, buffer solutions, and experimental instruments were stored in the anaerobic box for at least $24 \mathrm{~h}$ prior to use. To ensure strictly anaerobic conditions in the box, the reduction of methyl viologen (at $-446 \mathrm{mV}$ ) was carefully checked whenever the experimental procedures were carried out.

Biochemical tests. Biochemical reactions were tested according to the methods described in the Virginia Polytechnic Institute manual (2). End products produced in peptoneyeast extract-glucose broth (PYG) were assayed by gas chromatography, as described previously $(3,4)$.

DNA-DNA hybridization. DNA hybridization experiments with $E$. saphenus, E. nodatum, and Eubacterium strain D-6 were carried out, since phenotypical and morphological characteristics of $E$. saphenus were similar to those of $E$. nodatum and Eubacterium strain D-6. The level of DNA relatedness among $E$. saphenus, E. brachy, E. lentum, and $E$. timidum was also determined, because these asaccharolytic Eubacterium species are frequently isolated from the human oral cavity. E. combesii and E. dolichum were

TABLE 1. Levels of relatedness among strains of E. saphenus and six other Eubacterium spp.

\begin{tabular}{|c|c|c|c|c|c|c|}
\hline \multirow{2}{*}{ Competitive DNA from: } & \multirow{2}{*}{$\underset{(\mathrm{mol} \%)}{\mathrm{G}+\mathrm{C} \text { content }}{ }^{a}$} & \multicolumn{5}{|c|}{ \% Relatedness with labeled DNA from $E$. saphenus strain } \\
\hline & & U 133-14 & U 146-24 & $\mathrm{U} 164-47^{\mathrm{T}}$ & U 175-34 & U $183-27$ \\
\hline \multicolumn{7}{|l|}{ E. saphenus } \\
\hline U 133-14 & 46 & 100 & & & & \\
\hline U 146-24 & 48 & 96 & 100 & & & \\
\hline $\mathrm{U} 164-47^{\mathrm{T}}$ & 45 & 91 & 93 & 100 & & \\
\hline U $175-34$ & 44 & $>100$ & $>100$ & $>100$ & 100 & \\
\hline U $183-27$ & 45 & $>100$ & $>100$ & $>100$ & 83 & 100 \\
\hline E. brachy АТCC $33089^{\mathrm{T}}$ & 39 & 9 & 3 & 3 & 4 & 9 \\
\hline E. lentum ATCC $25559^{\mathrm{T}}$ & 62 & 2 & 1 & 1 & 1 & 3 \\
\hline E. limosum ATCC $8486^{\mathrm{T}}$ & 50 & 3 & 1 & 1 & 1 & 3 \\
\hline E. nodatum ATCC $33099^{\mathrm{T}}$ & 41 & 2 & 1 & 1 & 1 & 1 \\
\hline E. timidum ATCC $33093^{\mathrm{T}}$ & 50 & 4 & 2 & 1 & 8 & 6 \\
\hline Eubacterium strain D-6 D136M-28 & 64 & 2 & 1 & 1 & 1 & 1 \\
\hline
\end{tabular}

${ }^{a} \mathrm{G}+\mathrm{C}$ content was measured by high-performance liquid chromatography. $\mathrm{G}+\mathrm{C}$ values for $E$. nodatum and $E$. limosum had been reported as 38 to 40 and 47 mol\%, respectively, by the thermal denaturation method (9).

${ }^{*}$ Corresponding author. 
TABLE 2. Differential characteristics of E. saphenus and four other asaccharolytic Eubacterium species

\begin{tabular}{lccccc}
\hline \multicolumn{1}{c}{ Characteristic } & E. saphenus & E. brachy & E. lentum & E. nodatum & E. timidum \\
\hline Fermentation of carbohydrates & - & - & - & - & - \\
Product(s) $)^{a}$ (PYG cultures) & $\mathrm{a}, \mathrm{b}$ & ib, iv, ic, & $\mathrm{ND}^{b}$ & a, B & + \\
Arginine hydrolysis & - & phe-p & - & + & - \\
Nitrate reduction & - & - & + & - \\
\hline
\end{tabular}

a a, acetate; b, butyrate; ib, isobutyrate; iv, isovalerate; ic, isocaproate; phe-a, phenylacetate; phe-p, phenylpropionate. Capital letters represent an amount of product equal to or greater than $10 \mathrm{mM}$; small letters represent an amount of product less than $10 \mathrm{mM}$.

${ }^{b} \mathrm{ND}$, not determined.

excluded from the DNA hybridization experiment because the characteristics of both species (9) are different from those of $E$. saphenus. The bacterial cells were grown in BHI broth supplemented with $2 \%$ bovine serum and harvested by centrifugation. The cell pellet was resuspended in $5 \mathrm{ml}$ of saline-EDTA buffer $(0.15 \mathrm{M} \mathrm{NaCl}, 0.1 \mathrm{M}$ EDTA [pH 8.0]) and frozen. After three cycles of thawing and freezing, the suspension was subjected to ultrasonic treatment for $10 \mathrm{~min}$ and then incubated with $20 \mathrm{mg}$ of lysozyme at $37^{\circ} \mathrm{C}$ for 30 min. DNA was extracted by the method of Marmur (7).

DNA-DNA relatedness (\%) was determined by the membrane filter method described by Meyer and Schleifer (8). ${ }^{32}$ P-labeled DNA was prepared with the Multiprime DNA labeling system (Amersham, Buckinghamshire, United Kingdom), and the amount of radioactivity ranged from $10^{6}$ to $10^{7} \mathrm{cpm} / \mu \mathrm{g}$. Denatured ${ }^{32} \mathrm{P}$-labeled DNA $(0.015$ to 0.02 $\mu \mathrm{g})$ was incubated with unlabeled homologous or heterologous DNA (35 $\mu \mathrm{g}$ ) on a filter (type BA-85; diameter, $23 \mathrm{~mm}$; Schleicher \& Schuell, Dassel, Germany) in $1 \mathrm{ml}$ of $0.09 \mathrm{M}$ sodium citrate- $0.9 \mathrm{M}$ saline solution $(6 \times \mathrm{SSC})$ containing $0.02 \%$ bovine serum albumin (fraction V; Sigma), $0.02 \%$ polyvinylpyrrolidone, $0.02 \%$ Ficoll 400 , and $0.08 \%$ sodium dodecyl sulfate (SDS), at $60^{\circ} \mathrm{C}$ for $18 \mathrm{~h}$. After the filter was washed with $6 \times$ SSC and then $2 \times$ SSC and dried, the radioactivity of the hybridized DNA on the filter was counted with a liquid scintillation counter. Triplicate tests were run for each assay, and the results were normalized to $100 \%$ for the homologous DNAs.

$\mathbf{G}+\mathbf{C}$ contents. The $\mathrm{G}+\mathrm{C}$ content of DNA was measured by high-performance liquid chromatography (5).

SDS-PAGE. Whole bacterial cells (200 mg [wet weight]) were resuspended in $20 \mathrm{ml}$ of phosphate-buffered saline and ultrasonicated in a cooling system until more than $95 \%$ of the cells were disrupted, as determined by phase-contrast microscopy. The extract was centrifuged at $12,000 \times g$ for 30 min at $4^{\circ} \mathrm{C}$, and the supernatant was dialyzed against distilled water and lyophilized. SDS-polyacrylamide gel electrophoresis (SDS-PAGE) was carried out by the method of Laemmli (6) in $7.5 \%$ polyacrylamide gel $(1 \mathrm{~mm}$ thick), by using the Micro Slab Gel Electrophoresis System KS-8010 (Marysol Co., Tokyo, Japan). The lyophilized sample (50

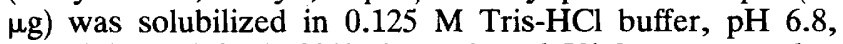
containing $4 \%$ SDS, $20 \%$ glycerol, and 5\% 2-mercaptoethanol for $10 \mathrm{~min}$ at $100^{\circ} \mathrm{C}$.

Electrophoresis was conducted at a constant current of 10 $\mathrm{mA}$ at room temperature. After electrophoresis, the gels were stained by Coomassie brilliant blue R-250 (Nakarai Chemicals, Ltd., Kyoto, Japan).

\section{RESULTS AND DISCUSSION}

DNA-DNA hybridization experiments revealed that five strains of the $U$ group were highly related genetically but clearly distinct from $E$. nodatum, Eubacterium strain D-6, and other asaccharolytic Eubacterium species studied (Table 1). SDS-PAGE patterns of the cell extract of the $U$ group strains were also distinct from those of the other species studied (data not shown). These results indicate that the U group strains should be assigned to a new species. Because the organisms had been hidden in the bacterial flora of periodontal pockets and their isolation had been difficult, we propose to name them $E$. saphenus. Phenotypic characteristics useful for differentiating $E$. saphenus from some other asaccharolytic Eubacterium species are shown in Table 2.

Description of Eubacterium saphenus sp. nov. Eubacterium saphenus (sa.phe.'nus. L. adj. hidden; referring to the fact that the organisms had been hidden in a bacterial flora).

The description below is based on a study of the five strains listed in Materials and Methods.

Cells are obligately anaerobic, non-spore-forming, nonmotile, gram-positive short rods ( 0.5 by 1.0 to $1.2 \mu \mathrm{m})$. Cells occur singly, in pairs, and sometimes in chains (Fig. 1). Cells from older cultures often stain gram negative. The growth is poor in broth media and moderately enhanced in the presence of $5 \%$ bovine serum, $0.2 \%$ lysine, or $0.2 \%$ arginine. Strictly anaerobic conditions are required for growth.

After incubation for 7 days in an anaerobic glove box (model AZ-Hard) containing $80 \%$ nitrogen with $10 \% \mathrm{H}_{2}$ and $10 \% \mathrm{CO}_{2}$, colonies on BHI-blood agar plates are 0.3 to 0.5 $\mathrm{mm}$ in diameter, circular, convex, and translucent. After 14 days, they are about $1.0 \mathrm{~mm}$ in diameter. No hemolysis is produced around colonies on BHI-blood agar plates.

Strains are nonfermentative and do not utilize adonitol, amygdalin, arabinose, cellobiose, erythritol, esculin, fructose, galactose, glucose, glycogen, inositol, lactose, maltose, mannose, mannitol, melezitose, melibiose, raffinose, rhamnose, ribose, salicin, sorbitol, starch, sucrose, trehalose, and xylose. Moderate amounts (ca. $5 \mathrm{mM}$ each) of butyrate and acetate are produced in peptone-yeast extract or PYG. They are inert in most of the usual biochemical tests: esculin and starch are not hydrolyzed, nitrate is not
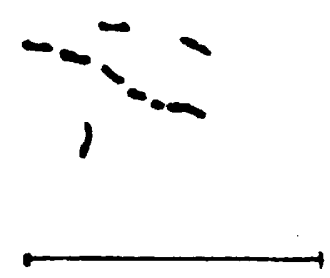

\section{$10 \mu \mathrm{m}$}

FIG. 1. Sketch of Gram-stained cells from BHI broth cultures (supplemented with $2 \%$ bovine serum) of E. saphenus ATCC $49989^{\mathrm{T}}$. 
reduced, no liquefaction of gelatin occurs, ammonia is not produced from arginine, indole is not produced, and catalase and urease are not produced. Ammonia production from arginine may be useful for differentiating this species from $E$. nodatum (Table 2).

Isolated from human periodontal pockets.

The $\mathrm{G}+\mathrm{C}$ content is 44 to $48 \mathrm{~mol} \%$.

The type strain is E. saphenus ATCC 49989.

\section{ACKNOWLEDGMENTS}

We thank L. V. H. Moore for the gift of a Eubacterium D-6 strain. This investigation was supported in part by The Japanese Ministry of Education, Science and Culture under grants-in-aid for scientific research $(61440076,03404055$, and 04807130).

\section{REFERENCES}

1. Hill, G. B., O. M. Ayers, and A. P. Kohhan. 1987. Characteristics and sites of infection of Eubacterium nodatum, Eubacterium timidum, Eubacterium brachy, and other asaccharolytic eubacteria. J. Clin. Microbiol. 25:1540-1545.

2. Holdeman, L. V., E. P. Cato, and W. E. C. Moore (ed.). 1977. Anaerobe laboratory manual, 4th ed. Virginia Polytechnic Institute and State University, Blacksburg.
3. Hoshino, E. 1985. Predominant obligate anaerobes in human carious dentin. J. Dent. Res. 64:1195-1198.

4. Hoshino, E., and M. Sato. 1986. Production and degradation of formate by Veillonella dispar ATCC 17745. J. Dent. Res. 65:903-905.

5. Katayama-Fujimura, Y., Y. Komatsu, H. Kuraishi, and T. Kaneko. 1984. Estimation of DNA base composition by high performance liquid chromatography of its nuclease P1 hydrolysate. Agric. Biol. Chem. 48:3169-3172.

6. Laemmil, U. K. 1970. Cleavage of structural proteins during the assembly of the head of bacteriophage T4. Nature (London) 277:680-685.

7. Marmur, J. 1961. A procedure for the isolation of DNA from microorganisms. J. Mol. Biol. 3:208-218.

8. Meyer, S. A., and K. H. Schleifer. 1978. DNA reassociation in the classification of coagulase-positive staphylococci. Arch. Microbiol. 117:183-188.

9. Moore, W. E. C., and L. V. H. Moore. 1986. Genus Eubacterium Prévot 1938, 294 ${ }^{\mathrm{AL}}$, p. 1353-1373. In P. H. A. Sneath, N. S. Mair, M. E. Sharpe, and J. G. Holt (ed.), Bergey's manual of systematic bacteriology, vol. 2. The Williams \& Wilkins Co., Baltimore.

10. Uematsu, H., and E. Hoshino. 1992. Predominant obligate anaerobes in human periodontal pockets. J. Periodontal Res. 27:1519. 